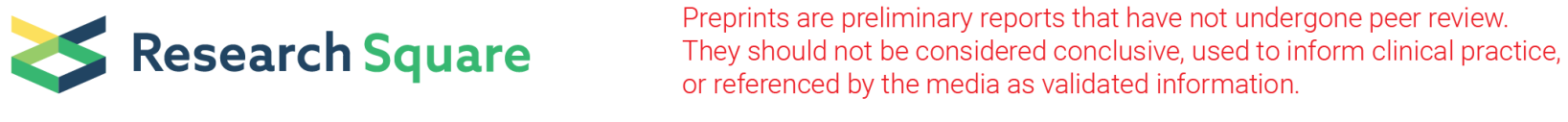

\title{
Genome-wide association mapping in wheat reveals novel QTLs and potential candidate genes involved in resistance to septoria tritici blotch
}

\author{
Mozghan Mahboubi \\ Islamic Azad University Sanandaj Branch \\ Reza Talebi ( rezatalebi56@gmail.com) \\ Islamic Azad University https://orcid.org/0000-0001-9109-7677 \\ Rahim Mehrabi \\ Isfahan University of Technology \\ Amir Mohammad Naji \\ Shahed University \\ Marco Maccaferri \\ University of Bologna: Universita di Bologna \\ Gert Kema \\ Wageningen UR PRI: Wageningen University and Research Wageningen Plant Research
}

Research Article

Keywords: Wheat, Zymoseptoria tritici, resistance, DArTseq, GWAS

Posted Date: May 4th, 2021

DOI: https://doi.org/10.21203/rs.3.rs-486336/v1

License: (1) This work is licensed under a Creative Commons Attribution 4.0 International License. Read Full License 


\section{Abstract}

Septoria tritici blotch (STB) caused by Zymoseptoria tritici is one of the most important foliar diseases of wheat that can lead to significant yield losses worldwide. In this study, we analyzed STB resistance pattern of 185 diverse bread wheat genotypes at the seedling stage in order to confirm known resistance genes or identifying novel putative QTLs conferring resistance to STB. The phenotyping data using $10 Z$. tritici isolates showed that large genetic variance exists for STB infection in wheat germplasm. Genome-wide association mapping (GWAS) using CMLM algorithm identified 37 quantitative-trait loci (QTL) for resistance to STB on 17 chromosomes. Most of QTLs overlapped with known STB resistance genes, while GWAS scan revealed several newly identified QTLs on chromosomes 4A, 5D and 6D for resistance to STB. Genome annotation of marker-trait association (MTA) against wheat reference genome revealed 29 MTAs corresponded to the putative genes, which their functional descriptions identifiers included diseases resistance proteins in plants. These MTAs and novel QTLs associated with STB resistance found here, can be used in future wheat breeding programs to recombine different loci for durable resistance to STB.

\section{Key Message}

Discovery of novel QTLs for resistance to Zymoseptoria tritici in hexaploid wheat on chromosomes 4A, 5D and 6D.

\section{Introduction}

Common wheat (Triticum aestivum L.) is the most important cereal crop in the world and plays important role in the diets of humans and livestock. Average global wheat production is about 766.4 million tons in 2019 (http://www.fao.org/worldfoodsituation/csdb/en). This makes wheat the third important crop in terms of production after maize and rice. Global wheat production can be negatively influenced by abiotic and biotic stresses. Septoria tritici blotch (STB) caused by Zymoseptoria tritici is one of the most destructive fungal diseases of wheat worldwide (Kema et al. 1996; Hardwick et al. 2001). The fungus causes expanded necrotic lesions from early-emerging leaves to flag leaves, and the overall damage caused by STB can result in grain yield losses up to 50\% under optimal environmental conditions (Mehrabi et al. 2006; Goodwin 2007; Kema and van Silfhout, 1997; Suffert et al. 2011). Under epidemic conditions, fungicide application is required to control STB, but this strategy is not adequately effective due to quick adaptation of the pathogen to fungicides by mutation (Torriani et al. 2009; Mohammadi et al. 2017; Kema et al. 2018). In addition, the application of fungicides has severe threats to human health and the environment. Therefore, the characterization of new resistance sources and the development of resistant wheat cultivars is the most economical and environmentally-friendly approach and fundamental strategy in breeding programs for sustainable agriculture and food security (Talebi et al. 2010; Mehrabi et al. 2015). Up to now, 22 major genes and 89 QTLs for resistance to Z. tritici have been reported and mapped on the wheat genome along with their closely linked markers (reviewed by Brown et al. 2015; Yang et al. 2018).

Both qualitative and quantitative resistance has been reported for resistance to STB in wheat. Qualitative resistance is usually controlled by major genes that confer complete resistance and follows by the gene-for-gene model (Brown et al. 2015). This model has been reported for the first time on Z.tritici isolate IP0323 and cv. Flame (Kema et al. 2000; Brading et al. 2002). Quantitative resistance is controlled by many minor genes and widely reported in wheat cultivars at both seedling and adult growth stages (Arraiano and Brown, 2006; Chartrain et al. 2004; Goodwin, 2007).

Although the qualitative resistance is effective and important for controlling STB, the rapid evolution and adaptation of Z.tritici populations result in overcoming resistance in most improved cultivars (Cowger et al. 2000; Stukenbruke et al. 2007; Makhdoomi et al. 2015; Muqaddasi et al. 2019). Therefore, in order to increase the durability of wheat resistance to STB, combining qualitative and quantitative resistance genes is required to preserve resistance effectiveness over time (Brown et al. 2015; Vagndorf et al. 2017). Availability of high-definition genotyping using genotype-bysequence (GBS) technologies enables breeders to identify resistance genes in diverse germplasm that can be employed for the development of new resistant cultivars using the gene pyramiding approach (Kidane et al. 2017; Vagndorf et al. 2017; Arraiano and Brown, 2017; Muqaddasi et al. 2019).

The genetic architecture of resistance to STB has been mostly evaluated in different bi-parental populations for detection of large-effect genes or quantitative trait loci (QTLs) (Chartrain et a. 2004, 2005a,b,c; Simon et al. 2005; Tabib Ghaffary et al. 2011, 2012). Genome-wide association mapping (GWAS) using a large number of markers with high genome coverage is a powerful tool for detecting the resistance loci associated with diverse germplasm possessing natural variation of resistance genes (Bartoli and Roux, 2017). Various GWAS studies have been performed on diverse wheat germplasm (Mirdita et al. 2015; Vagndorf et al. 2017; Kidane et al. 2017; Gerard et al. 2017; Muqaddasi et al. 2019; Arraiano and Brown, 2017). Most previous GWAS studies for revealing QTLs against STB have been done for detecting resistance loci against a mixture of isolates under natural field conditions. Therefore, GWAS analysis for specific-isolate resistance using globally diverse pathotypes of $Z$. tritici is of great interest for breeders to identify new genes/loci that can be used in wheat breeding programs.

The present study relies on genotyping and phenotyping of a globally diverse panel of 185 wheat genotypes that were evaluated at the seedling stage against $10 \mathrm{Z}$. tritici isolates (collected from Iran, Algeria, Turkey, France and The Netherlands). DNA fingerpring of the wheat genotypes was performed using high-throughput DArTseq technology (SilicoDArT and SNP markers) aiming to identify and localize possible novel QTLs associated with isolate-specific resistance against $Z$. tritici in wheat.

Page 2/20 


\section{Materials And Methods}

\section{Plant material and evaluation of STB infection}

The 185 wheat genotypes comprised 64 Iranian improved cultivars, 103 accessions from globally diverse origins, and 18 wheat differential lines with known STB genes (Supplementary Table S1). Phenotypic evaluation of wheat genotypes against 10 Z. tritici isolates (Table 1) was described in detail by Mahbubi et al. (2020). Phenotyping of wheat genotypes was done under greenhouse conditions at the seedling stage as described previously (Abrinbana et al. 2012; Makhdoomi et al. 2015). Briefly, STB isolates were pre-cultured in yeast-extract glucose (YG) liquid medium, and then these pre-cultures were used to inoculate $100 \mathrm{ml} \mathrm{YG} \mathrm{media} \mathrm{per} \mathrm{isolate.} \mathrm{YG} \mathrm{media} \mathrm{were} \mathrm{placed} \mathrm{in} \mathrm{an} \mathrm{orbital} \mathrm{shaker} \mathrm{(set} \mathrm{at} 125 \mathrm{rpm}$ ) and incubated at $18^{\circ} \mathrm{C}$ for 5-6 days. The propagated yeast-like spores were collected and their concentrations were adjusted to $10^{7}$ spores/ml. Five seeds of each genotype were sown in plastic pods and 10-day old seedlings were spray-inoculated using hand sprayers. Inoculated plants were kept in dark plastic bags for $48 \mathrm{~h}$ at $20-25^{\circ} \mathrm{C}$ and then transferred to a greenhouse with the environmental condition of $18-22{ }^{\circ} \mathrm{C}$ and $>85 \%$ humidity (Kema et al. 1996). After 3-weeks, the plants were scored visually based on the percentage of necrotic leaf area covered by pycnidia as described before (Kema et al. 1996; Ghaneie et al. 2012). Experiments were set up with a randomized complete block design with three replications.

\section{Phenotypic data analysis}

Data were normalized using arcsin square root-transformation (Sokal and Rolhf, 1995). Normalized data were analyzed using a linear mixed model (LMM), in which the isolates and wheat genotypes were the main effects and their two-way interaction as fixed effects. The effects of replication (block) and experiment were considered as random effects. Broad sense heritability estimates were calculated for best linear unbiased estimates (BLUE) values from all STB isolates. BLUE values were then used for cluster analysis, correlation analysis and also to perform GWAS.

Cluster analysis of wheat genotypes according to pycnidia coverage data by each isolate was performed using the un-weighted pair-group method (UPGMA) and the dissimilarity matrix was measured using the Ward's method implemented in PAST software (Hammer et al. 2001). Pearson correlation coefficients among 10 STB isolates were calculated for the percentage of leaf covered by pycnidia in 185 wheat genotypes.

\section{Genotypic data}

DNA was extracted from seedling plants of each genotype using the CTAB protocol (Lasner et al. 1989). The quality and quantity of DNA were checked by spectrophotometer, and DNA concentration was adjusted to $100 \mathrm{ng} / \mu \mathrm{l}$. DNA samples were plated in $96-\mathrm{plex}$ and shipped to DArT Pty Ltd, Canberra, Australia, and genotyped using the DArTseq technology (Sansaloni et al. 2011; Alam et al. 2018). The detailed methodology for the generation of DArTseq markers (SNP and SilicoDArT) was described before (Egea et al. 2017). We received a total of 94535 (54309 SilicoDArT and 40225 SNP) markers, which were polymorphic across 185 wheat genotypes. Marker loci with unknown chromosome positions (based on genome assembly) were removed from the analysis, and the remaining markers were filtered using a minimum minor allele frequency (MAF) of 0.01 in TASSEL v.5.2.37 software (Bradbury et al., 2007). Wheat is a self-pollinated crop and we assumed that all genotypes are homozygous. Therefore markers showing heterozygous were indicated as missing and markers with >10\% missing were excluded. In total, 21773 (15856 SilicoDArT and 5917 SNP) distributed across the 21 chromosomes were maintained for analysis (Supplementary Table S2).

\section{Linkage disequilibrium and population structure analysis}

Linkage disequilibrium (LD) for DArTseq markers was implemented in TASSEL v.5.2.37. The critical $r^{2}$-value was determined by root transforming the unlinked $r^{2}$-values and taking the 95th percentile of the distribution as the threshold beyond which LD is likely caused by genetic linkage (Nielsen et al. 2014; Monostori et al. 2017). The graphical LD decay was imputed by the GAPIT R package (VanRaden, 2008; Lipka et al., 2012). Population structure was performed in STRUCTURE 2.1 based on an admixture model (Evanno et al., 2005). Model run as the burn of 10000 iterations followed by 10000 Markov Chain Monte Carlo iterations was set for accurate parameter estimates. The optimal value of $\mathrm{K}$ ranging from 1 to 10 , with three independent runs. Principal coordinate analysis (PCoA) and cluster analysis among the wheat genotypes estimated in DARwin ver. 5.0 software using the Unweighted Neighbor-Joining (UNJ) algorithm.

\section{Genome-wide association analysis}

Genome-wide association mapping (GWAS) analysis for resistance to 10 Z.tritici isolates in a panel of 185 wheat genotypes was conducted in R package Genome Association and Prediction Integrated Tool (GAPIT) (Lipka et al. 2012) using all 21773 DArTseq markers. Association analyses were done using different models like GLM, MLM, CMLM and Super-MLM models. It has been reported that the MLM model is better than GLM by controlling false positive and also MLM able to control false positive disappear in GWAS analysis for complex traits in a panel of genotypes that show extensive genetic divergence (Yu et al. 2006; Kaler et al. 2020), but in some cases, MLM model may lead to false negatives and consequently weakness of marker-trait associations (MTAs) (Zhang et al. 2010). Compressed mixed linear model (CMLM) improves the statistical power of analysis. Finally, all models were compared for false positives and false negatives based on the Q-Q plots. CMLM showed the best results and final GWAS analysis was performed in this model. 
In order to detect the marker-trait association (MTA) in GWAS, the significance threshold for MTA was set to $P=0.05$ after applying the false discovery rate (FDR) correction. Phenotypic data for all isolates gave models that did not cross the false discovery rate threshold, and therefore, the arbitrary threshold of significance of $-\log 10(P) \geq 3.0$ corresponding to a $P$-value of 0.001 was accepted as significant MTA (Vagndorf et al. 2017; Muqaddasi et al. 2019). Map positions of significant MTAs were determined according to their genetic positions in a high-resolution DArT-seq consensus map (version 4.0), provided by Dr. Andrzej Kilian (Diversity Arrays Technology Pty Ltd, Canberra, Australia) and bread wheat IWGSC RefSeq v1.04 with BLAST+ v2.7.1 (Camacho et al. 2009). Overlapping markers on the same chromosome for resistance to different STB isolates were considered to tag a single QTL if their positions were closer than $10 \mathrm{cM}$ and showed LD $r^{2}>0.3$. Then for comparison of the QTLs identified in this study, the position of each QTL was projected onto the wheat SSR consensus map (Somer et al. 2004; Maccaferri et al. 2015) for crossreference with previous SSR maps. Each QTL considered new if its position was $\geq 10 \mathrm{cM}$ from previously reported STB resistance genes or QTLs.

Candidate genes for individual MTAs were identified by aligning the physical position of markers to the sequence of the wheat genome assembly IWGSC v.1.0 (https://plants.ensembl.org/Triticum_aestivum/Info/Index). High-confidence annotated genes were retrieved from a $10 \mathrm{~kb}$ window of left and right of each identified MTA.

\section{Results}

\section{Phenotypic data analysis}

Analysis of disease severity data showed significant differences ( $P \otimes 0.001)$ among wheat genotypes for resistance to $Z$. tritici (Table 2$)$. Genotype $\times$ isolate interaction was highly significant $(P \otimes 0.001)$ and indicated the differences in wheat genotypes for their responses to $Z$. tritici isolates. Heritability values for disease severity were high for all isolates. The high heritability values indicated that there was a limited replication variation relative to genotypic variation for all isolates. This is supported by high Pearson correlation coefficients for disease severity between all isolates (Table 3). The Pearson correlation coefficient between STB isolates ranged from 0.26 (IP002166 and IP092034) to 0.90 (IPO323 and IP086013) with an average value of 0.61 (Table 3). In total, 239 isolate-specific resistances were found among all interactions ( $\mathrm{n}=1850$ ), of which 183 showed disease severity $P \leq 5 \%$ (highly resistance), 56 were disease severity $5<P \leq 10 \%$ (resistance) (Supplementary Table S1).

The mean disease severity (DS) among wheat genotypes ranged from 0\% (M3 synthetic) to 68\% (KC4821 from Iran). Among 64 Iranian commercial cultivar and lines, 51 genotypes (80\%) were susceptible to all isolates, while ER-M-92-20 was resistant to all isolates. In addition, Saison, Gaspard and Naaz showed resistance responses to all isolates, except for IP002166. In total, 39 isolate-specific resistances were found among all interactions $(n=640)$. The overall mean disease severity among Iranian commercial cultivar and lines was $45 \%$ ranging from $2 \%(E R-M-$ 92-20) to $62 \%$ (Parsi).

Cluster analysis and principal component analysis using omitted data from the percentage of leaf area covered by pycnidia, grouped wheat genotypes in three distinct clusters (Fig 1). The first cluster comprised 63 wheat genotypes, of which 19 genotypes were Iranian cultivar and breeding lines, 7 genotypes with previously known Stb genes (Bulgaria, Israel 493, Cs-Synthetic, Shafir, Es-Federal, M6 and Balance) and the remaining genotypes originated from diverse origins. Resistance spectra of genotypes for this cluster ranged from $30.98 \%$ (IP0323) to $56.61 \%$ (IP002166) (Table 4). Cluster-II contained 85 genotypes, with 32 Iranian cultivars, one differential cultivar (Curtot) and 52 genotypes from diverse origins. All genotypes in this cluster showed a highly susceptible pattern to most of the isolates and the mean disease severity ranged from $45.14 \%$ (IP0323) to 66.57\% (IP002166) (Table 4). Cluster III comprised 37 genotypes, which most of the differentials with known Stb genes (Veranopolis, Tadinia, Kavkaz-K4500, TE9111, Salamoni, Arina, Riband and M3) grouped in this cluster. In general, genotypes belonging to this cluster showed low mean disease severity ranged from 7.76\% (IP0323) to 43.59\% (IP002166) (Table 4). Cluster-III comprised of 37 genotypes, including 13 Iranian cultivar and breeding lines, eight differentials (Veranopolis, Tadinia, Kavkaz-K4500, TE9111, Salamoni, Arina, Riband and M3) and 16 landraces from different origins. In general, genotypes grouped in this cluster had a low mean disease severity ranging from $7.76 \%$ (IPO323) to $43.59 \%$ (IP002166) (Table 4).

\section{Population structure and linkage disequilibrium}

Extensive genotyping on 185 wheat genotypes resulted in 21773 (15856 SilicoDArT and 5917 SNP) markers. The Unweighted Neighbor-Joining cluster analysis (Fig 2a) and Bayesian model-based structure analysis (Fig 2b) grouped wheat genotypes into four distinct subpopulations. Subpopulation 1 (50 genotypes) consisted of 17 Iranian landrace genotypes and other genotypes that were mainly from Western Asia and Eastern Europe (Turkey, Tajikistan, Romania, Hungary). Sub-population 2 (29 genotypes) consisted mostly of genotypes from diverse origins and two Iranian cultivars. Sub-population 3 (86 genotypes) comprised most of the Iranian improved genotypes (45 genotypes) and eight wheat differentials for resistance to STB. Sub-population 4 (20 genotypes) consisted of landraces accessions from different origins. In general, there was no strong significant relationship between cluster grouping and origin of wheat genotypes, most probably due to the ancient and recent international exchange of germplasm, while the Iranian improved cultivars mainly grouped in the same cluster. Several of the genotypes used in this study have been utilized as parental lines or have the same pedigree background, so a mixture of origins was observed in all clusters. Nevertheless, a clear distinction on the above-mentioned four main subpopulations was clearly observed based on molecular data analysis. Principal component analysis (PCA) was used to confirm the results of population structure and also showed a distinct pattern of subpopulations. The first two PCs

Page $4 / 20$ 
represented $66.72 \%$ of the total variation (Fig 2c). A comparable result similar to cluster analysis and PCA was also observed by the heatmap plot of kinship matrix where four distinct clusters were identified (Fig 3). Different subpopulations showed different resistance levels for most of the isolates. Subpopulation 1 (mostly of Iranian landraces and landraces from West Asia) has the highest susceptibility (mean DS=48.2), followed by the subpopulation 2 (mean DS=43.4) and subpopulation 3 and 4 (mean DS are 43.3 and 40.4, respectively) (Fig 4). These associations between population structure and STB resistance indicated that corrections for population structure were required for association mapping analysis.

In LD analysis the square of the correlation coefficient of alleles between loci $\left(r^{2}\right)$ was not significant for most of the pairwise comparisons, whereas out of 1048575 marker pairs only 297546 (28\%) intra-chromosomal pairs showed a significant level $(P<0.001)$ of LD. Marker pairs on the genome-B showed a higher number of significant pairs in comparison to the genome-A and genome-D. Mean and critical $r^{2}$ values were 0.09 and 0.16 , respectively. LD declined with increasing physical genetic distances between markers and $r^{2}$ value falling below the critical value over distances of $1.6 \mathrm{~kb}$ (Fig 5).

\section{Genome-Wide Association Analysis}

Among different GWAS models, CMLM model shows reliable results and presented low spurious associations. For the analysis, phenotypic data (percentage of necrotic leaf area covered by pycnidia) and 21773 mapped DArTseq markers on 185 wheat genotypes were used. The highest number of markers mapped on A genome (8031) and B genome (9537) compared to those mapped on D genome (4205). Association analysis was performed separately for each isolate. A total of 67 significant MTAs $(P<0.001)$ were identified for STB resistance on 17 chromosomes (Table 5). Manhattan plots for the association between markers and STB responses in different isolates were displayed in Supplementary Figure 1.

The QTLs identified by different isolates but located at overlapping genomic region on a chromosome were considered a single QTL and assigned the same name using the nomenclature Qstb-iau-followed by the number of QTL in chromosome order (Table 5; Supplementary Figure S2), and finally 37 QTLs were detected on 17 chromosomes (Table 5). Overall, most QTLs showed small effects and the proportion of phenotypic variation explained by each MTA for disease severity (\% of leaf area covered by pycnidia) ranged from 7.28 to $13.74 \%$ (Table 5).

The position of these QTLs was compared to the position of mapped QTLs and known genes reported in previous studies (Summarized in Supplementary Figure 2). Results showed that $28 \mathrm{QTLs}$ identified in overlap regions or very close to genomic regions in previously reported QTLs/genes. Out of 37 QTLs, ten QTLs were identified as novel QTLs for resistance to STB. Two QTLs on chromosomes 1A and 1B (Qstb-iau-2 and Qstb-iau-3, respectively) were mapped far from any reported known STB genes or QTLs on these chromosomes. Qstb-iau-12 on chromosome 2D and another three QTLs (Qstb-iau-17, Qstb-iau-18 and Qstb-iau-19) on chromosome 4A are localized far from previously mapped QTLs and genes. Four other QTLs (Qstb-iau-22, Qstb-iau-23, Qstb-iau-26, Qstb-iau-32) also were mapped on chromosomes 5B, 5D and 6D. These QTLs mapped in novel genomic regions as compared to previously known genes/QTLs for resistance to STB.

\section{Putative candidate gene identification}

All the MTAs associated with resistance to STB isolates identified by CMLM method were mapped to the wheat physical genome (described in the materials \& methods section). The physical reference genome of Chinese Spring cv. was used to survey the genes in the flanking regions on each MTA (IWGSC RefSeq v1.04 with BLAST+ v2.7.1). We restricted the gene survey to a $10 \mathrm{~Kb}$ region, covering $5 \mathrm{~Kb}$ regions toward the left and right side of the MTA markers to survey the genes more precisely. Out of 68 MTAs, 39 MTAs showed the sequences on wheat reference genome without characterized molecular function. However, 29 MTAs corresponded to the putative genes, which their functional descriptions identifiers included the most famous disease resistance proteins in plants. Some examples are UDP-glucosyltransferase on chromosome 2D, P-loop-NTPase on chromosome $2 \mathrm{D}$ and 6D, leucine-rich repeat on chromosome $2 \mathrm{~B}$ and $6 \mathrm{~B}$ and othe well-known genes like as Cytochrome P450, Alkalinephosphatase, Oxidoreductase, Patatin-like phospholipase and Haem peroxidase (Table 5).

\section{Discussion}

\section{Novel sources for resistance to Z. tritici}

Zymoseptoria tritici is one of the most important foliar diseases in many wheat-growing areas, including Europe, Northern America and Asia (Hardwick et al. 2001; Mehrabi et al. 2015). The use of genetic resistance is the most appropriate strategy to control the disease. However, the rapid adaptation of $Z$. tritici populations leads to a quick breakdown of resistance and. Thus, continuous characterization and utilization of new sources of resistance in breeding programs are prerequisites (Abrinbana et al. 2010; Ghaneie et al. 2012). Iran is one of the primary centers of origin of wheat, and it is proposed that the co-evolution of wheat and Z. tritici occurred in this region. Therefore, the characterization of resistant wheat genotypes using isolates from this region is likely required to increase the durability of resistance (Ghaneie et al. 2012; Makhdomi et al. 2015; Aghamiri et al. 2015). We have recently studied the interactions of 185 wheat genotypes against $10 Z$. tritici isolates from different sources (Mahboubi et al. 2020). Most wheat genotypes showed a susceptible pattern to all isolates. High broad-sense heritability suggested that the resistance variation is heritable, which are in agreement with previous studies on septoria resistance in different wheat germplasm in both seedling and adult plant stages (Dreisigacker et al. 2015; Muqaddasi et al. 2019; Riaz et al. 2020).

Page $5 / 20$ 
Among the isolates, IP0323 showed the highest number of incompatible interactions (n=35), while IP002166 (originated from Iran) showed a high level of aggressiveness on wheat genotypes. Most of the wheat differentials possessing known Stb genes were susceptible to most of $Z$. tritici isolates, which are in agreement with previous reports for the ineffectiveness of known Stb genes against $Z$. tritici populations (Abrinbana et al. 2012; Makhdoomi et al. 2015; Mahboubi et al. 2020). Interestingly, two genotypes (ER-M-92-20 and IPK40740) and four differentials (Kavkaz$\mathrm{K} 4500$, Arina, Riband and M3) were resistant to all isolates. These genotypes could be of interest as resistance sources that contain resistance genes or a combination of diverse yet-unknown Stb genes. Previous reports indicated that Stb6 was ineffective against studied isolates (Mahboubi et al. 2020). Therefore, it can be concluded that the high resistance pattern of these genotypes should be due to the presence of Stb15 or new unknown resistance genes. Besides these highly resistant genotypes, five genotypes (IPK45227, IPK26116, IPK41079, IPK16452 and IPK40793) showed resistance to nine isolates and can be used as valuable resistance sources in wheat breeding programs. Among all genotypes, M3 showed highly resistance (immune) responses to all isolates. This genotype contains Stb16 and Stb17 (Tabib Ghaffary et al. 2012; Mahboubi et al. 2020). Therefore, it can be concluded that this gene still is effective against STB, which is consistent with previous (Hosseinnezhad et al. 2014; Makhdoomi et al. 2015). The resistant genotypes identified in this study are likely novel sources of resistance, which can be used in breeding programs for the development of modern wheat cultivars.

\section{QTL validation and alignment to previously reported STB genes and QTLs}

In line with our previous study, we used GWAS analysis to identify novel QTLs against $Z$. tritici isolates. This approach enables breeders to enhance crop genetic improvement by incorporating suitable QTLs into wheat breeding programs (Ibrahim et al. 2020). To this aim, DArTseq markers were successfully used to genotype a globally diverse wheat germplasm. The use of high-density markers with broad genome coverage in GWAS improved the accuracy of identified QTLs for resistance to STB, which is a highly quantitative disease trait with a minor contribution of each QTL (Mirdita et al. 2015; Muqaddasi et al. 2019). Overall, we found 37 QTLs for resistance to STB that were located on 17 chromosomes (Table 5). The phenotypic variation explained by each QTL mapped on different chromosomes was relatively low $\left(R^{2} \leq 0.14\right)$, suggesting that the resistance to this pathogen follows a highly quantitative nature, which is consistent with previous reports (Kidane et al. 2017; Arraiano and Brown, 2017; Yates et al. 2019).

The precise comparisons of these QTLs with known QTLs were difficult due to different populations, isolates and markers used elsewhere. However, using consensus wheat maps, it was possible to compare QTLs with the mapped chromosomal location of previously known genes/QTLs. Most of the QTLs identified in this study were localized in adjacent regions with known QTLs that have previously been identified (Goudemand et al. 2013; Brown et al. 2015). For example, the QTLs mapped on chromosomes 3B (Qstb.iau-14), 5A (Qstb.iau-21) and 5B (Qstb.iau24) were mapped in close chromosomal position of Stb14 (Cowling, 2006), Stb17(Tabib Ghaffary et al. 2012) and Stb1 (Adhikari et al. $2004 b)$. In addition, QTLs on chromosomes 6A and 7B associated with resistance to IP086013 may also represent Stb15 (Arraiano et al. 2007b) and Stb8/Stb13 (Adhikari et al. 2003; Cowling, 2006), respectively (Supplementary Figure 2). Other identified QTLs in this study on chromosomes 2B, 5A, 7A and 7D also may represent Stb9 (Chartrain et al. 2009), Stb17(Tabib Ghaffary et al. 2012), TmStb1 (Jing et al. 2008 ) and Stb4/Stb5 (Adhikari et al. 2004a; Arraiano et al. 2001), respectively. Furthermore, we found several QTLs in close position of Meta-QTLs for resistance to Z. tritici isolates at both seedling and adult stages reported by Goudemand et al. (2013). Therefore, QTLs identified in this study can be used as valuable sources for introgression of these QTLs into advanced wheat lines (Odilbekov et al. 2019).

In addition to previously known QTLs, we found several novel QTLs. On chromosome 5D, a new QTL (Qstb.iau-26) was identified for resistance to IP086013 isolate. This QTL is localized distantly from recently reported QTLs on this chromosome (Yates et al. 2019). This region on chromosome $5 \mathrm{D}$ is also known as the introgressed region from Aegilops umbellulata and Ae. tauschii into wheat and is an important chromosomal location having resistance genes against leaf rust, stripe rust, soil-borne mosaic virus and powdery mildew (Bansal et al. 2020; Mohler et al. 2020; Liu et al. 2020; Fu et al. 2014). Additionally, we found two novel QTLs on chromosome 4A (Qstb.iau-17 and Qstb.iau-18) and a QTL on chromosome 6D (Qstb.iau-32), which are distantly localized far from the known STB genes (Stb7/Stb12 and Stb18 mapped on chromosomes 4A and 6D, respectively). Therefore, we assume these QTLs could be novel QTLs associated with resistance to STB. In addition, we detected novel genomic regions on chromosomes $1 A, 1 B, 2 D$ and $5 B$, in which their chromosomal positions were not overlapped with previously known QTLs/genes. Detection of these novel QTLs provided useful information that could be used to track favorable alleles for developing wheat cultivars resistant to STB. This knowledge can be used for generation of new allelic combination through cross between novel sources for resistance to STB (Riaz et al. 2020). Lastly, some QTLs identified in this study were co-located with known STB genes or previously mapped Meta-QTLs for resistance to STB at the seedling and adult stages in the field (Goodwin et al. 2015; Goudemand et al. 2013). This suggests that these QTLs remain effective as durable sources for resistance to STB against isolates from diverse countries (Riaz et al. 2020).

\section{Annotation of disease resistance genes}

We characterized 29 MTAs corresponded to the putative genes functionally related to disease resistance in plants (Table 5). Intervals on chromosome 2A contained genes that were enriched for cytochrome P450, papain-like cysteine protease, zinc finger protein and chloramphenicol acetyltransferase-like protein. Cytochrome P450s (CYPs) belong to the oxidoreductases class of enzymes and their potential roles in xenobiotic metabolism are well characterized in plant species for resistance to various biotic and abiotic stresses (Yan et al. 2016; Pandian et al. 2020). It has been shown that a pathogen-induced CYP82C2 gene and other possible CYPs play important roles against the bacterial canker pathogen 
(Pseudomonas syringae) (Rajniak et al. 2015). Papain-like cysteine proteases (PLCPs) control key processes and are a central hub in plant immunity (Richau et al. 2012; Misas-Villamil et al. 2016). F-Box Protein CPR1 is well-known for its effect on plastid function in the absence of pathogens (Hedtmann et al. 2017). Secondary metabolism plant glycosyltransferases (UGTs) are a large family of plant genes known for their putative function during plant-pathogen interactions (Langlois-Meurinne et al. 2005). He et al. (2018) carried out a genome-wide analysis of family1 UDP glycosyltransferases in wheat and their results showed that DP-glycosyltransferase enzymes (UGTs) were involved in detoxification as well as FHB resistance by glycosylating DON into DON-3-glucoside (D3G). Other intervals corresponded to some putative genes enriched for proteins containing leucine-rich repeat protein, anti-microbial extrusion protein, protein kinase and Haem peroxidase (Table 5), which are well-known genes for their significant roles in plants for resistance against biotic stresses (Kushalappa et al. 2016; Andersen et al. 2018; Han, 2019).

\section{Conclusion}

Resistance to STB is genetically complex and thus identification and comparison of QTLs for multiple isolates can be informative for designing appropriate breeding programs (Goodwin, 2007; Eriksen et al. 2003; Mirdita et al. 2015; Poppe et al. 2015; Mirzadi Gohari et al. 2015; Haueisen et al. 2019). Association mapping is a powerful genetic tool to identify chromosomal locations and QTLs related to disease resistance. This strategy has been used to detect QTLs against $Z$. tritici. However, the majority of these studies were conducted based on field trials under the epidemic condition (Vagndorf et al. 2017; Arraiano and Brown 2017; Moqaddasi et al. 2019) or plants inoculated by limited isolates (Odilbekov et al. 2019). In this study, we used a large number of $Z$. tritici isolates $(n=10)$ originated from different countries against a panel of worldwide diverse wheat genotypes to perform a deep genome association study. In addition, we used known sequence-based markers (SilicoDArT and SNP) annotated to the wheat reference genome to find the possible function of identified QTLs/genes. Although, most of the QTLs identified in this study co-localized with previously known STB QTLs/genes, several novel genomic regions associated with resistance to multiple $Z$. tritici isolates were identified. The QTL localized on chromosome 5D confers resistance to IP086013 isolate and QTLs on chromosomes 4A and 6D confer resistance to multiple isolates. Interestingly, based on physical mapping of QTLs against available reference genome sequence, we characterized several candidate genes involved in plant defense mechanisms against pathogens. These genes are of interest and their exact roles in STB resistance remain to be functionally analyzed in the future.

Identification of wheat genotypes possessing new QTLs/alleles is an important step in breeding programs towards introgression of these QTLs into new modern cultivars. Molecular and functional characterization of these QTLs/genes eventually will enhance our understanding of how resistance is achieved and sheds light on biochemical mechanisms underlying resistance against STB.

\section{Declarations}

Acknowledgements: The authors acknowledge the Iranian Seed and Plant Improvement Institute (SPII) for their kind support in germplasm preparation and diseases phenotyping experiments.

Author contributions: MM contributed in disease phenotyping and wrote the manuscript. RT and RM planned and designed the research, performed in analysis and wrote the manuscript. AMN performed the analysis. MM and GK read, edited and approved the manuscript.

Funding: Partial financial support was received from Islamic Azad University, Sanandaj Branch, Iran.

Data availability: The data used in this study are available as electronic Supplementary Materials.

\section{Compliance with ethical standards}

Conflict of interest: The authors declare that there is no conflict of in-terest.

Consent to participate 'Not applicable'.

Consent for publication 'Not applicable'.

Ethics approval 'Not applicable'.

\section{References}

Gerard GS, Borner A, Lohwasser U, Simon MR (2017) Genome-wide association mapping of genetic factors controlling Septoria tritici blotch resistance and their associations with plant height and heading date in wheat. Euphytica 213:27.

Abrinbana, M., Mozafari, J., Shams-bakhsh, M., Mehrabi, R. (2010). Genetic structure of Mycosphaerella graminicolapopulations in Iran. Plant Pathol 59:829-838. 
Abrinbana M, Mozafari J, Shams-Bakhsh M, Mehrabi R (2012) Resistance spectra of wheat genotypes and virulence patterns of Mycosphaerella graminicola isolates in Iran. Euphytica 186:75-90.

Adhikari TB, Anderson JM, Goodwin SB (2003) Identification and molecular mapping of a gene in wheat conferring resistance to Mycosphaerella graminicola. Phytopathology 93(9):1158-1164

Adhikari TB, Cavaletto JR, Dubcovsky J, Gieco JO, Schlatter AR, Goodwin SB (2004a) Molecular mapping of the Stb4 gene for Resistance to Septoria tritici Blotch in Wheat. Phytopathology 94(11): 1198-1206

Adhikari TB, Yang X, Cavaletto JR, Hu X, Buechley G, Ohm HW, Shaner G., Goodwin SB (2004b) Molecular mapping of Stb1, a potentially durable gene for resistance to Septoria tritici blotch in wheat. Theor Appl Genet 109:944-953.

Aghamiri A, Mehrabi R, Talebi R (2015) Genetic diversity of Pyrenophera tritici-repentis isolates, the causal agent of wheat tan spot disease from Northern Iran. Iran J Biotech 13(2):e1118.

Alam M, Neal J, O'Connor K, Kilian A, Topp B (2018) Ultra-high-throughput DArTseq-based silicoDArT and SNP markers for genomic studies in macadamia. PLoS ONE 13(8):e0203465.

Andersen EJ, Ali S, Byamukama E, Yen Y, Nepal MP (2018) Disease resistance mechanisms in plants. Genes 9:39.

Arraiano LS, Brown JKM (2017) Sources of resistance and susceptibility to Septoria tritici blotch of wheat. Mol Plant Pathol 18 (2):276-292.

Arraiano L, Brown J (2006) Identification of isolate-specific and partial resistance to septoria tritici blotch in 238 European wheat cultivars and breeding lines. Plant Pathol 55 (6):726-738.

Arraiano LS, Chartrain L, Bossolini E, Slatter HN, Keller B, Brown JKM (2007) A gene in European wheat cultivars for resistance to an African isolate of Mycosphaerella graminicola. Plant Pathol 56:73-78.

Arraiano LS, Worland AJ, Ellerbrook C, Brown JKM (2001b) Chromosomal location of a gene for resistance to Septoria trictici blotch (Mycosphaerella graminicola) in the hexaploid wheat 'Synthetic 6x'. Theor Appl Genet 103:758-764.

Bansal M, Adamski NM, Toor PI, Kaur S, Molnar I, Holušova K, Vrana J, Doležel D, Valarik M, Uauy C, Chhuneja P (2020) Aegilops umbellulata introgression carrying leaf rust and stripe rust resistance genes Lr76 and Yr70 located to 9.47-Mb region on 5DS telomeric end through a combination of chromosome sorting and sequencing. Theor Appl Genet 133:903-915

Bartoli C, Roux F (2017) Genome-Wide Association Studies InPlant Pathosystems: Toward anEcological Genomics Approach. Front Plant Sci $8: 763$.

Bradbury PJ, Zhang Z, Kroon DE, Casstevens TM, Ramdoss Y, Buckler ES (2007) TASSEL: software for association mapping ofcomplex traits in diverse samples.Bioinformatics 23: 2633-2635.

Brading PA, Verstappen ECP, Kema GHJ, Brown JKM (2002) A gene-for-gene relationship between wheat and Mycosphaerella graminicola, the Septoria tritici blotch pathogen. Phytopathology 92:439-445.

Brown J K, Chartrain L, Lasserre-Zuber P, Saintenac C (2015) Genetics of resistance to Zymoseptoria tritici and applications to wheat breeding. Fungal Genet Biol 79: 33-41.

Camacho C, Coulouris G, Avagyan V, Ma N, Papadopouloset J, Bealer K, Madden TL (2009) BLAST+: architecture and applications. BMC Bioinformatics 10:421.

Chartrain L, Berry ST, Brown JKM (2005a) Resistance of wheat line Kavkaz-K4500 L.6.A.4 to Septoria tritici blotch controlled by isolate-specific resistance genes. Phytopathol 95:664-671.

Chartrain L, Brading PA, Brown JKM (2005b) Presence of the Stb6 gene for resistance to Septoria tritici blotch (Mycosphaerella graminicola) in cultivars used in wheat-breeding programmes worldwide. Plant Pathol 54:134-143.

Chartrain L, Brading PA, Widdowson JP, Brown JKM (2004) Partial resistance to Septoria tritici blotch (Mycosphaerella graminicola) in the wheat cultivars Arina and Riband. Phytopathol 94:497-504.

Chartrain L, Joaquim P, Berry ST, Arraiano LS, Azanza F, Brown JKM (2005c) Genetics of resistance to Septoria tritici blotch in the Portuguese wheat breeding line TE9111. Theor Appl Genet 110:1138-1144. 
Chartrain L, Sourdille P, Bernard M, Brown JKM (2009) Identification and location of Stb9, a gene for resistance to Septoria tritici blotch in wheat cultivars Courtot and Tonic. Plant Pathol 58:547-555.

Cowger C, Hoffer ME, Mundt CC (2000) Specific adaptation by Mycosphaerella graminicola to a resistant wheat cultivar. Plant Pathol 49:445-451.

Cowling SG (2006) Identification and Mapping of Host Resistance Genes to Septoria tritici Blotch of Wheat. Ph.D. thesis, University of Manitoba.

Dreisigacker S, Wang X, Cisneros BAM, Jing R, Singh PK (2015) Adult-plant resistance toSeptoria tritici blotch inhexaploid spring wheat. Theor Appl Genet 128:2317-2329.

Egea LA, Mérida-García R, Kilian A,Hernandez P and Dorado G (2017)Assessment of Genetic Diversityand Structure of Large Garlic (Allium sativum) Germplasm Bank, byDiversity Arrays Technology“Genotyping-by-Sequencing”Platform (DArTseq). Front Genet 8:98.

Eriksen L, Borum F, Jahoor A (2003) Inheritance and localisation of resistance to Mycosphaerella graminicola causing Septoria tritici blotch and plant height in the wheat (Triticum aestivum L.) genome with DNA markers. Theor Appl Genet 107:515-527.

Evanno G, Regnaut S, Goudet J (2005) Detecting the number of clusters ofindividuals using the software STRUCTURE: a simulation study. Mol Ecol $14: 2611-2620$.

Fu S, Ren Z, Chen X, Yan B, Tan F, Fu T, Tang Z (2014) New wheat-rye 5DS-4RS_4RL and 4RS-5DS-5DL translocation lines with powdery mildew resistance. J Plant Res 127:743-753

Ghaneie A, Mehrabi R, Safaie N, Abrinbana M, Saidi A, Aghaee M (2012) Genetic variation for resistance to septoria tritici blotch in Iranian tetraploid wheat landraces. Eur J Plant Pathol 132 (2):191-202.

Goodwin SB, Cavaletto JR, Thomson I, Xu SS, Adhikari TB, Dubcovsky J (2015) A new map location of gene Stb3 for resistance to septoria tritici blotch in wheat. Crop Sci 55(1):35-43.

Goodwin SB (2007) Back to basics and beyond: increasing the level of resistance to Septoria tritici blotch in wheat. Australas. Plant Pathol $36: 532-538$.

Goudemand E, Laurent V, Duchalais L, Ghaffary SMT, Kema GHJ, Lonnet P, Margalé E, Robert O (2013) Association mapping and meta-analysis: two complementary approaches for the detection of reliable Septoria tritici blotch quantitative resistance in bread wheat (Triticum aestivum L.). Mol Breed 32:563-584.

Hammer $\emptyset$, Harper DAT, Ryan PD (2001) Paleontological statistics software package for education and data analysis. Palaeontol Electron 4: $9 \pm 18$. Han GZ (2019) Origin and evolution of the plant immune System. New Phytologist 222: 70-83.

Hardwick NV, Jones DR, Slough JE (2001) Factors affecting diseases in winter wheat in England and Wales, 1989-98. Plant Pathol 50:453-462.

Haueisen J, Möller M, Eschenbrenner CJ, Grandaubert J, Seybold H, Adamiak H, Stukenbrock EH (2019) Highly flexible infection programs in a specialized wheat Pathogen. Ecol Evol 9:275-294.

He Y, Ahmad D, Zhang X, Zhang Y, Wu L, Jiang P, Ma H (2018) Genome-wide analysis of family-1 UDP glycosyltransferases (UGT) and identification of UGT genes for FHB resistance in wheat (Triticum aestivum L.). BMC Plant Biol 18:67.

Hedtmann C, Guo W, Reifschneider E, Heiber I, Hiltscher H, van Buer J, Barsch A, Niehaus K, Rowan B, Lortzing T, Steppuhn A and Baier M (2017) The plant immunity regulating F-Box protein CPR1 supports plastid function in absence of pathogens.Front. Plant Sci 8:1650.

Hosseinnezhad A, Khodarahmi M, Rezaee S, Mehrabi R, Roohparvar R (2014) Effectiveness determination of wheat genotypes and Stb resistance genes against Iranian Mycosphaerella graminicola isolates. Arch Phytopathol Plant Protec 47(17):2051-2069.

Ibrahim AK, Zhang L, Niyitanga S, Afzal MZ, Yi Xu Y, Zhang L, Zhang L, Qi J (2020) Principles and approaches of association mapping in plant breeding. Trop Plant Biol 13:212-224

Jing HC, Lovell D, Gutteridge R, Jenk D, Kornyukhin D, Mitrofanova OP, Kema GH, Hammond-Kosack KE (2008) Phenotypic and genetic analysis of the Triticum monococcum - Mycosphaerella graminicola interaction. New Phytol 179:1121-1132.

Juliana P, Singh RP, Singh PK, Poland JA, Bergstrom GC, Huerta-Espino J, Bhavani S, Crossa J, Sorrells ME (2018) Genome-wide association mapping for resistance to leaf rust, stripe rust and tan spot in wheat reveals potential candidate genes. Theor Appl Genet 131:1405-1422. 
Kaler AS, Gillman JD, Beissinger T, Purcell LC (2020) Comparing different statistical models and multiple testing corrections for association mapping in soybean and maize. Front Plant Sci 10:1794.

Kema GH, Gohari AM, Aouini L, Gibriel HA, Ware SB, van Den Bosch F, Manning-Smith R, Alonso-Chavez V, Helps J, M’Barek SB (2018) Stress and sexual reproduction affect the dynamics of the wheat pathogen effector AvrStb6 and strobilurin resistance. Nature Genet 50 (3):375

Kema GHJ, Van Silfhout CH (1997) Genetic variation for virulence and resistance in the wheat-Mycosphaerella graminicola pathosystem. III. Comparative seedling and adult plant experiments. Phytopathol 87: 26672.

Kema GHJ, Sayoud R, Annone JG, van Silfhout CH (1996) Genetic variation for virulence and resistance in the wheat-Mycosphaerella graminicola pathosystem. 2. Analysis of interactions between pathogen isolates and host cultivars.Phytopathol 86:213-220.

Kema GHJ, Verstappen ECP, Waalwijk C (2000) Avirulence in the wheat Septoria tritici leaf blotch fungus Mycosphaerella graminicola is controlled by a single locus. Mol Plant Microbe Interact 13:1375-1379.

Kidane YG, Hailemariam BN, Mengistu DK, Fadda C, Pè ME and Dell'Acqua M (2017) Genome-Wide Association Study of Septoria tritici Blotch Resistance in Ethiopian Durum Wheat Landraces. Front Plant Sci 8:1586.

Kushalappa AC, Yogendra KN, Karre S (2016) Plant innate immune response: qualitative and quantitative resistance. Critical Rev Plant Sci 35(1): 38-55

Langlois-Meurinne M, Gachon CMM, Saindrenan P (2005) Pathogen-responsive expression of Glycosyltransferase genes UGT73B3 and UGT73B5 Is necessary for resistance to Pseudomonas syringae pv tomato in arabidopsis. Plant Physiol 139:1890-1901

Lassner MW, Peterson P, Yoder JI (1989) Simultaneous amplification of multiple DNA fragments by polymerase chain reaction in the analysis of transgenic plants and their progeny. Plant Mol Biol Report 7:116-128.

Lipka AE, Tian F, Wang Q, Peiffer J, Li M, Bradbury PJ, Gore MA, Buckler ES, Zhang Z. GAPIT: genome association and prediction integrated tool. Bioinformatics 28(18):2397-9.

Liu S, Bai G, Lin M, Luo M, Dadong D, Jin F, Tian B, Trick HN, Yan L (2020) Identification of candidate chromosome region of Sbwm1 for Soil-borne wheat mosaic virus resistance in wheat. Sci Rep 10:8119.

Maccaferri M, Zhang J, Bulli P, Abate Z, Chao SH, Cantu D, Bossolini E, Chen X, Pumphery M, Dubcovsky J (2015) A genome-wide association study of resistance to stripe rust (Puccinia striiformis $f$. sp. tritici) in a worldwide collection of hexaploid spring wheat (Triticum aestivum L.). G3 5:449465.

Mahboubi M, Talebi R, Aghaee Sarbarzeh M, Naji AM, Mehrabi R (2020) Resistance and virulence variability in wheat-Zymoseptoria tritici interactions. Crop Pasture Sci 71(7) 645-652.

Makhdoomi A, Mehrabi R, Khodarahmi M, Abrinbana M (2015) Efficacy of wheat genotypes and Stb resistance genes against Iranian isolates of Zymoseptoria tritici. J Gen Plant Pathol 81(1):5-14.

McCartney CA, Brûlé-Babel AL, Lamari L, Somers DJ (2003) Chromosomal location of a race specific resistance gene to Mycosphaerella graminicola in the spring wheat ST6. Theor Appl Genet 107:1181-1186.

Mehrabi R, Makhdoomi A, Jafar-Aghaie M (2015) Identification of new sources of resistance to septoria tritici blotch caused by Zymoseptoria tritici. J Phytopathol 163 (2):84-90.

Mehrabi R, van der Lee T, Waalwijk C, Kema GHJ (2006) MgSIt2, a cellular integrity MAP kinase gene of the fungal wheat pathogen Mycosphaerella graminicola, is dispensable for penetration but essential for invasive growth. Mol Plant Microbe Interact 19:389-398.

Mirdita V, Liu G, Zhao Y, Miedaner T, Longin CFH, Gowda M, Mette MF, Reif JC (2015) Genetic architecture is more complex for resistance to Septoria tritici blotch than to Fusarium head blight in Central European winter wheat. BMC Genom 16:430.

Mirzadi Gohari A, Ware SB, Wittenberg AH, Mehrabi R, Ben M'Barek S,Verstappen EC, van der Lee TA, Robert O, Schouten HJ, de Wit PP, Kema GHJ (2015) Effector discovery in the fungal wheat pathogen Zymoseptoria tritici. Mol Plant Pathol 16: 931-945.

Misas-Villamil JC, Hoorn RAL, Doehlemann G (2016) Papain-like cysteine proteases as hubs in plant immunity. New Phytol 212:902-907.

Mohammadi N, Mehrabi R, Gohari AM, Mohammadi GE, Safaie N, Kema GHJ (2017) The ZtVf1 transcription factor regulates development and virulence in the foliar wheat pathogen Zymoseptoria tritici . Fungal Genet Biol 109:26- 35. 
Mohler V, Schmolke M, Zeller FJ, Hsam SLK (2020) Genetic analysis of Aegilops tauschii-derived seedling resistance to leaf rust in synthetic hexaploid wheat. J Appl Genet 61:163-168

Monostori I, Szira F, Tondelli A, Arendas T, Gierczik K, Cattivelli L, Galiba G, Vagujfalvi A (2017) Genome-wide association study and genetic diversity analysis on nitrogen use efficiency in a Central European winter wheat (Triticum aestivum L.) collection. PLoS ONE 12(12):e0189265.

Muqaddasi QH, Zhao Y, Rodemann B, Plieske J, Ganal MW, Röder MS (2019) Genome-wide association mapping and prediction of adult stage blotch infection in european winter wheat via high-density marker arrays. Plant Genome 12 (1).

Nielsen NH, Backes G, Stougaard J, Andersen SU, Jahoor A (2014) Genetic diversity and population structure analysis of European hexaploid bread wheat (Triticum aestivum L.) varieties. PLoS One 9:e94000.

Odilbekov F, Armoniené R, Koc A, Svensson J and Chawade A (2019) GWAS-assisted genomic prediction to predict resistance to septoria tritici blotch in nordic winter wheat at seedling stage. Front Genet 10:1224.

Pandian BA, Sathishraj R, Djanaguiraman M, Prasad PVV, Jugulam M (2020) Role of Cytochrome P450 enzymes in plantstress response. Antioxidants 9:454

Poppe S, Dorsheimer L, Happel P, Stukenbrock EH (2015) Rapidly evolving genes are key players in host specialization and virulence of the fungal wheat pathogen Zymoseptoria tritici (Mycosphaerella graminicola). PLoS Pathog 11(7): e1005055.

Rajniak J, Barco B, Clay NK, Sattely ES (2015) A new cyanogenic metabolite in Arabidopsis required for inducible pathogen defence. Nature 525:376-379.

Riaz A, KockAppelgren P, Hehir JG, Kang J , Meade F, Cockram J , Milbourne D , Spink J, Mullins E, Byrne S (2020) Genetic analysis using a multiparent wheat population identifies novel sources of septoria tritici blotch resistance. Genes 11:887.

Richau KH, Kaschani F, Verdoes M, Pansuriya TC, Niessen S, Stuber K, Colby T, Overkleeft HS, Bogyo M, Van der Hoorn RAL (2012)

Subclassification and biochemical analysis of plant papain-likecysteine proteases displays subfamily-specific characteristics. Plant Physiol 158:1583-1599.

Sansaloni CP, Petroli CD, Carling J, Hudson CJ, Steane DA, Myburg AA,Grattapaglia D, Vaillancourt RE, Kilian A (2011) A high-density Diversity Arrays Technology (DArT) microarray for genome-wide genotyping in Eucalyptus. Plant Methods 6:16.

Simón MR, Worland AJ, Struik PC (2005) Chromosomal location of genes encoding for resistance to septoria tritici blotch (Mycosphaerella graminicola) in substitution lines of wheat. NJAS Wagening J Life Sci 53:113-129.

Sokal RR, Rohlf FJ(1995) Biometry: The principles and practice of statistics in biological research,3rd edition. W.H. Freeman and Company, New York.

Somers DJ, Isaac P, Edwards K (2004) A high-density microsatellite consensus map for bread wheat (Triticum aestivum L.). Theor Appl Genet 109:1105-1114.

Stukenbrock EH, Banke S, Javan-Nikkhah M, McDonald BA (2007) Origin and domestication of the fungal wheat pathogen Mycosphaerella graminicola via sympatric speciation. Mol Biol Evol 24:398-411.

Suffert F, Sache I, Lannou C (2011) Early stages of septoria tritici blotch epidemics of winter wheat: build-up, overseasoning, and release of primary inoculum. Plant Pathol 60:166-177.

Tabib Ghaffary SM, Faris JD, Friesen TL, Visser RGF, van der Lee TAJ, Robert O, Kema GHJ (2012) New broad-spectrum resistance to Septoria tritici blotch derived from synthetic hexaploid wheat. Theor Appl Genet 124:125-142.

Tabib Ghaffary SM, Robert O, Laurent V, Lonnet P, Margale E, van der Lee TAJ, Visser RGF, Kema GHJ (2011) Genetic analysis of resistance to Septoria tritici blotch in the French winter wheat cultivars Balance and Apache. Theor Appl Genet 123:741-754.

Talebi R, Mardi M, Jelodar NB, Razavi M, Pirseyedi SY, Kema G, Mehrabi R, Marcel T (2010) Specific resistance genes in wheat chinese landrace 'Wangshuibai' against two Iranian Mycosphaerella graminicola isolates. Int J Biol 2:181-188.

Torriani SF, Brunner PC, McDonald BA, Sierotzki H (2009) Qol resistance emerged independently at least 4 times in European populations of Mycosphaerella graminicola. Pest Manag Sci 65 (2):155-162. 
Vagndorf N, Nielsen NH, Edriss V, Andersen JR, Orabi J, Jørgensen LN, Jahoor A (2017) Genome-wide association study reveals novel quantitativetrait loci associated with resistance towards Septoria tritici blotch in North European winter wheat. Plant Breed 136(4):474-482.

Van Damme EJM, Lannoo N, Peumans WJ (2008) Plant lectins. Adv Bot Res 48:107-209.

VanRaden PM (2008) Efficient methods to compute genomic predictions.J. Dairy Sci 91:4414-4423.

Yan Q, Cui X, Lin S, Gan S, Xing H, Dou D (2016) GmCYP82A3, a Soybean Cytochrome P450Family Gene Involved in the Jasmonic Acid and Ethylene Signaling Pathway, Enhances PlantResistance to Biotic and Abiotic Stresses. PLoS ONE 11(9): e0162253.

Yang N, McDonald MC, Solomon PS, Milgate AW (2018) Genetic mapping of Stb19, a new resistance gene to Zymoseptoria tritici in wheat. Theor Appl Genet 131(12):2765-2773.

Yates S, Mikaberidze A, Krattinger SG, Abrouk M, Hund A, Yu K, Studer B, Fouche S, Meile L, Pereira D, Karisto P, McDonald BA (2019) Precision phenotyping reveals novel loci for quantitative resistance to septoria tritici blotch. Plant Phenomics 2019: 3285904

Yu J, Pressoir G, Briggs WH, Vroh BI, Yamasaki M, Doebley JF, McMullen MD, Gaut BS, Nielsen DM, Holland JB, Kresovich S, Buckler ES (2006) A unifed mixed-model method for association mapping that accounts for multiple levels of relatedness. Nat Genet 38:203-208.

Zhang Z, Ersoz E, Lai CQ, Todhunter RT, Tiwari HK, Gore MA, Bradbury PJ, Yu J, Arnett DK, Ordovas JM, Buckler ES (2010) Mixed linear model approach adapted for genome-wide association studies. Nat Genet 42:355-360.

\section{Tables}

Table 1. List of isolates used for phenotypic analysis on 185 wheat genotypes at seedling stage under greenhouse conditions.

\begin{tabular}{|lll|}
\hline Isolates code & Origin & \\
\hline IP002166 & Country & Location \\
\hline IP099031 & France & Pezful \\
\hline IP098022 & France & Villaines la Gonais \\
\hline IP092034 & Algeria & Guelma \\
\hline IP086013 & Turkey & Adana \\
\hline IP0323 & Netherlands & W.rabant \\
\hline RM230 & Iran & Bokan \\
\hline RM22 & Iran & Khozestan \\
\hline RM6 & Iran & Fars \\
\hline RM183 & Iran & Ardabil \\
\hline
\end{tabular}

Table 2. Summary of the linear mixed model (LMM) of percentages of leaf area with necrotic lesions bearing pycnidia of 10 isolates of Zymoseptoria tritici on 185 wheat genotypes

\begin{tabular}{|lllll|}
\hline Fixed effect & Wald statistics & d.f. & Wald/d.f. & $P^{a}$ \\
\hline Genotype & 7718.23 & 184 & 41.94 & $* \star \star$ \\
\hline Isolate & 1398.49 & 9 & 155.38 & $* \star \star$ \\
\hline Genotype $\times$ Isolate & 14317.59 & 1656 & 8.64 & $* \star \star$ \\
\hline
\end{tabular}

Table 3. Pearson correlation coefficient and broad-sense heritability $\left(h^{2}\right)$ for response to Zymoseptoria tritici isolates against 185 wheat genotypes across three replication under controlled greenhouse conditions. 


\begin{tabular}{|c|c|c|c|c|c|c|c|c|c|c|c|}
\hline Isolates & IP002166 & IP099031 & RM230 & RM22 & RM6 & RM183 & IP098022 & IP092034 & IP086013 & IP0323 & Heritability \\
\hline \multirow[t]{2}{*}{ IP002166 } & 1 & & & & & & & & & & \\
\hline & & & & & & & & & & & 0.98 \\
\hline IP099031 & $0.57 \star \star$ & 1 & & & & & & & & & 0.97 \\
\hline RM230 & $0.28^{*}$ & $0.52^{\star}$ & 1 & & & & & & & & 0.97 \\
\hline RM22 & $0.49 *$ & $0.64^{\star \star}$ & $0.63^{* \star}$ & 1 & & & & & & & 0.99 \\
\hline RM6 & $0.45^{\star}$ & $0.55^{\star \star}$ & $0.55^{\star \star *}$ & $0.80 \star \star$ & 1 & & & & & & 0.99 \\
\hline RM183 & $0.47^{*}$ & $0.58^{\star \star *}$ & $0.60 * *$ & $0.84 * *$ & $0.90 * *$ & 1 & & & & & 0.97 \\
\hline IP098022 & $0.37^{*}$ & $0.48^{\star}$ & $0.54^{\star \star}$ & $0.75^{\star \star}$ & $0.81^{\star *}$ & $0.85^{\star \star}$ & 1 & & & & 0.92 \\
\hline IP092034 & $0.26^{*}$ & $0.39 *$ & $0.45^{\star}$ & $0.65^{\star \star}$ & $0.66^{\star *}$ & $0.69 * *$ & $0.80^{\star \star}$ & 1 & & & 0.98 \\
\hline IP086013 & $0.31^{*}$ & $0.42^{\star}$ & $0.48^{*}$ & $0.70 \star \star$ & $0.71^{\star \star}$ & $0.75^{\star \star}$ & $0.82^{\star \star}$ & $0.82^{\star *}$ & 1 & & 0.98 \\
\hline IP0323 & $0.29 *$ & $0.41^{*}$ & $0.48^{\star}$ & $0.68^{\star *}$ & $0.73^{\star *}$ & $0.74^{\star *}$ & $0.81^{* *}$ & $0.79 * *$ & $0.90^{\star *}$ & 1 & 0.95 \\
\hline
\end{tabular}

Table 4. Means of disease severity of wheat genotypes to different Zymoseptoria tritici isolates in three clusters

\begin{tabular}{|llllllllllll|}
\hline Cluster & No.Genotypes & IP02166 & IP099031 & RM230 & RM22 & RM6 & RM183 & IP09802250 & IP092034 & IP086013 & IP0323 \\
\hline 1 & 63 & 56.61 & 43.10 & 44.24 & 39.15 & 38.06 & 39.92 & 35.79 & 38.44 & 40.61 & 30.98 \\
\hline 2 & 85 & 66.57 & 60.78 & 53.89 & 55.49 & 61.12 & 59.91 & 54.32 & 51.61 & 50.68 & 45.14 \\
3 & 37 & 43.59 & 30.39 & 25.77 & 15.03 & 13.34 & 13.16 & 9.28 & 8.22 & 9.08 & 7.76 \\
\hline
\end{tabular}

Table 5. Summary of the septoria tritici blotch resistance quantitative trait loci identified against 10 Zymoseptoria tritici isolates in the panel of 185 wheat genotypes. 


\begin{tabular}{|c|c|c|c|c|c|c|c|c|}
\hline QTL & $\begin{array}{l}\text { Associated } \\
\text { marker }\end{array}$ & Isolate & Chr. & $\begin{array}{l}\text { Physical } \\
\text { Position }\end{array}$ & $\begin{array}{l}\text { Position } \\
\text { (cM) }\end{array}$ & $\begin{array}{l}\mathrm{R} 2 \\
(\%)\end{array}$ & Annotatted gene & Function \\
\hline $\begin{array}{l}\text { Qstb- } \\
\text { iau-1 }\end{array}$ & 5332931 & RM6,RM183 & $1 \mathrm{~A}$ & 2187418 & 7.5 & 10.08 & & \\
\hline $\begin{array}{l}\text { Qstb- } \\
\text { iau-2 }\end{array}$ & 2257844 & RM186 & $1 \mathrm{~A}$ & 460566539 & 90.73 & 9.19 & TraesCS1A02G264800 & $\begin{array}{l}\text { Domain of unknown } \\
\text { function DUF630 }\end{array}$ \\
\hline $\begin{array}{l}\text { Qstb- } \\
\text { iau-3 }\end{array}$ & 1264502 & IP086013 & 1B & 18654882 & 44.37 & 11.99 & & \\
\hline $\begin{array}{l}\text { Qstb- } \\
\text { lau-4 }\end{array}$ & 1063031 & RM6, RM183, RM230 & $2 \mathrm{~A}$ & 143209404 & 69.95 & 8.69 & TraesCS2A02G183200 & $\begin{array}{l}\text { Palmitoyltransferase, } \\
\text { DHHC domain }\end{array}$ \\
\hline \multirow[t]{3}{*}{$\begin{array}{l}\text { Qstb- } \\
\text { iau-5 }\end{array}$} & 1124086 & RM6 & $2 \mathrm{~A}$ & 695351850 & 82.25 & 8.70 & TraesCS2A02G446100 & $\begin{array}{l}\text { Ubiquitin- } \\
\text { conjugating } \\
\text { enzyme/RWD-like }\end{array}$ \\
\hline & 1065743 & RM183 & $2 \mathrm{~A}$ & 695161475 & 83.25 & 9.19 & TraesCS2A02G445700 & $\begin{array}{l}\text { E3 ubiquitin ligase } \\
\text { RBR family/Zinc } \\
\text { finger }\end{array}$ \\
\hline & 1137616 & RM6 & $2 \mathrm{~A}$ & 694759982 & 83.59 & 8.66 & TraesCS2A02G444600 & $\begin{array}{l}\text { Calcium/proton } \\
\text { exchanger CAX }\end{array}$ \\
\hline \multirow{2}{*}{$\begin{array}{l}\text { Qstb- } \\
\text { iau-6 }\end{array}$} & 4544165 & IP099031 & $2 \mathrm{~A}$ & 748128615 & 113.78 & 8.46 & TraesCS2A02G530100 & Cytochrome P450 \\
\hline & 3533473 & IP099031 & $2 \mathrm{~A}$ & 776037491 & 120.68 & 9.14 & TraesCS2A02G584900 & $\begin{array}{l}\text { Papain-like cysteine } \\
\text { peptidase } \\
\text { superfamily }\end{array}$ \\
\hline \multirow[t]{2}{*}{$\begin{array}{l}\text { Qstb- } \\
\text { iau-7 }\end{array}$} & 3064517 & IP0323 & $2 \mathrm{~B}$ & 11132 & 0.57 & 8.71 & TraesCS2B02G000100 & $\begin{array}{l}\text { Chloramphenicol } \\
\text { acetyltransferase-like }\end{array}$ \\
\hline & 1864355 & IP0323, IP086013 & $2 \mathrm{~B}$ & 11066 & 1.26 & 9.18 & & \\
\hline \multirow{2}{*}{$\begin{array}{l}\text { Qstb- } \\
\text { iau-8 }\end{array}$} & 1151413 & IP002166 & $2 \mathrm{~B}$ & 209974991 & 72 & 7.95 & & \\
\hline & 2292325 & RM183 & $2 B$ & 159841515 & 75.1 & 9.29 & & \\
\hline \multirow{2}{*}{$\begin{array}{l}\text { Qstb- } \\
\text { iau-9 }\end{array}$} & 1253215 & RM22, RM183 & $2 \mathrm{~B}$ & 539295298 & 89.7 & 8.50 & TraesCS2B02G376300 & Leucine-rich repeat \\
\hline & 1093912 & IP098022 & $2 \mathrm{~B}$ & 775155639 & 96.12 & 11.32 & TraesCS2B02G588300 & $\begin{array}{l}\text { Tetratricopeptide-like } \\
\text { helical domain } \\
\text { superfamily }\end{array}$ \\
\hline \multirow[t]{3}{*}{$\begin{array}{l}\text { Qstb- } \\
\text { iau- } \\
10\end{array}$} & 1265720 & RM230 & $2 \mathrm{D}$ & 12587173 & 11.54 & 13.74 & TraesCS2D02G031300 & $\begin{array}{l}\text { UDP- } \\
\text { glucuronosyl/UDP- } \\
\text { glucosyltransferase }\end{array}$ \\
\hline & 1092168 & IP002166 & $2 \mathrm{D}$ & 16270193 & 16.9 & 8.35 & & \\
\hline & 3937084 & RM6, RM22 & $2 \mathrm{D}$ & 22776052 & 21.81 & 10.14 & TraesCS2D02G057100 & $\begin{array}{l}\text { Wax synthase } \\
\text { domain }\end{array}$ \\
\hline \multirow{2}{*}{$\begin{array}{l}\text { Qstb- } \\
\text { iau- } \\
11\end{array}$} & 4991389 & RM22 & $2 \mathrm{D}$ & 203822266 & 73.57 & 8.13 & & \\
\hline & 1696840 & RM22 & $2 \mathrm{D}$ & 203822332 & 73.57 & 8.52 & & \\
\hline \multirow[t]{2}{*}{$\begin{array}{l}\text { Qstb- } \\
\text { iau- } \\
12\end{array}$} & 3384824 & IP002166 & $2 \mathrm{D}$ & 639104562 & 105.5 & 7.91 & TraesCS2D02G574500 & $\begin{array}{l}\text { P-loop containing } \\
\text { nucleoside } \\
\text { triphosphate } \\
\text { hydrolase }\end{array}$ \\
\hline & 1020861 & IP086013 & $2 D$ & 641868694 & 107.04 & 11.61 & & \\
\hline $\begin{array}{l}\text { Qstb- } \\
\text { iau- } \\
13\end{array}$ & 1028519 & RM22 & $2 \mathrm{D}$ & 646461966 & 148.92 & 11.63 & TraesCS2D02G590400 & $\begin{array}{l}\text { Glycosyltransferase } \\
61\end{array}$ \\
\hline \multirow{2}{*}{$\begin{array}{l}\text { Qstb- } \\
\text { iau- } \\
14\end{array}$} & 1034676 & RM6 & $3 B$ & 347461150 & 49.22 & 8.44 & & \\
\hline & 1205624 & IP098022 & $3 B$ & 310392089 & 53.24 & 11.50 & & \\
\hline
\end{tabular}

Page 14/20 


\begin{tabular}{|c|c|c|c|c|c|c|c|c|}
\hline $\begin{array}{l}\text { Qstb- } \\
\text { iau- } \\
15\end{array}$ & 1124803 & IP0323 & $3 B$ & 557176126 & 65.26 & 7.76 & & \\
\hline $\begin{array}{l}\text { Qstb- } \\
\text { iau- } \\
16\end{array}$ & 1086457 & IP092034 & $3 B$ & 781962409 & 122.38 & 9.32 & & \\
\hline \multirow{2}{*}{$\begin{array}{l}\text { Qstb- } \\
\text { iau- } \\
17\end{array}$} & 1152519 & IP098022 & $4 \mathrm{~A}$ & 7326080 & 14.50 & 9.76 & TraesCS4A02G012800 & $\begin{array}{l}\text { Mitochondrial carrier } \\
\text { domain superfamily }\end{array}$ \\
\hline & 5582113 & $\begin{array}{l}\text { IP098022,IP099031, } \\
\text { RM6, RM22, RM183 }\end{array}$ & $4 \mathrm{~A}$ & 140700686 & 21.83 & 11.64 & & \\
\hline $\begin{array}{l}\text { Qstb- } \\
\text { iau- } \\
18\end{array}$ & 2257551 & $\begin{array}{l}\text { RM6, RM22, RM183, } \\
\text { RM230 }\end{array}$ & $4 \mathrm{~A}$ & 641506835 & 96.35 & 9.18 & TraesCS4A02G369500 & $\begin{array}{l}\text { Alkaline- } \\
\text { phosphatase-like }\end{array}$ \\
\hline \multirow{2}{*}{$\begin{array}{l}\text { Qstb- } \\
\text { iau- } \\
19\end{array}$} & 1238557 & RM230 & $4 \mathrm{~A}$ & 722708344 & 121.39 & 13.33 & & \\
\hline & 4004033 & RM230 & $4 \mathrm{~A}$ & 723286159 & 122.5 & 12.83 & & \\
\hline
\end{tabular}

Table 5. Continue 


\begin{tabular}{|c|c|c|c|c|c|c|c|c|}
\hline QTL & $\begin{array}{l}\text { Associated } \\
\text { marker }\end{array}$ & Isolate & Chr & $\begin{array}{l}\text { Physical } \\
\text { Position }\end{array}$ & $\begin{array}{l}\text { Position } \\
\text { (cM) }\end{array}$ & $\begin{array}{l}\mathrm{R} 2 \\
(\%)\end{array}$ & Annotatted gene & Function \\
\hline $\begin{array}{l}\text { Qstb- } \\
\text { iau-20 }\end{array}$ & 12763870 & RM183 & $4 \mathrm{~B}$ & 656492378 & 58.8 & 9.76 & & \\
\hline $\begin{array}{l}\text { Qstb- } \\
\text { iau-21 }\end{array}$ & 2258488 & RM6, RM183 & $5 \mathrm{~A}$ & 568491318 & 80.07 & 9.53 & & \\
\hline $\begin{array}{l}\text { Qstb- } \\
\text { iau-22 }\end{array}$ & 1210062 & IP099031 & $5 B$ & 50290704 & 26.12 & 7.28 & & \\
\hline \multirow[t]{2}{*}{$\begin{array}{l}\text { Qstb- } \\
\text { iau-23 }\end{array}$} & 5970385 & IP002166 & $5 B$ & 488112132 & 44.5 & 8.87 & TraesCS5B02G303800 & $\begin{array}{l}\text { Oxidoreductase, N- } \\
\text { terminal domain }\end{array}$ \\
\hline & 1088825 & IP002166 & $5 B$ & 490053583 & 45.23 & 8.52 & & \\
\hline \multirow{3}{*}{$\begin{array}{l}\text { Qstb- } \\
\text { iau-24 }\end{array}$} & 1115292 & RM22, RM183 & $5 B$ & 641326900 & 61.13 & 7.79 & & \\
\hline & 2354562 & $\begin{array}{l}\text { IP092034, } \\
\text { IP099031,RM22, } \\
\text { RM183 }\end{array}$ & $5 B$ & 557353675 & 78.82 & 11.26 & TraesCS5B02G379300 & $\begin{array}{l}\text { Patatin-like } \\
\text { phospholipase } \\
\text { domain }\end{array}$ \\
\hline & 1111946 & RM183 & $5 B$ & 566697556 & 79.34 & 9.79 & TraesCS5B02G387600 & Tetratricopeptide-like \\
\hline \multirow[t]{2}{*}{$\begin{array}{l}\text { Qstb- } \\
\text { iau-25 }\end{array}$} & 1139663 & $\begin{array}{l}\text { IP086013, IP092034, } \\
\text { RM6, RM183 }\end{array}$ & $5 B$ & 708325171 & 146.83 & 11.47 & TraesCS5B02G562500 & $\begin{array}{l}\text { Multi antimicrobial } \\
\text { extrusion protein }\end{array}$ \\
\hline & 1262194 & RM183 & $5 B$ & 710271842 & 150.32 & 9.61 & & \\
\hline \multirow{2}{*}{$\begin{array}{l}\text { Qstb- } \\
\text { iau-26 }\end{array}$} & 6038202 & IP086013 & $5 \mathrm{D}$ & 541681037 & 137.5 & 11.30 & & \\
\hline & 7157166 & IP086013 & $5 \mathrm{D}$ & 541902658 & 138.2 & 11.35 & & \\
\hline $\begin{array}{l}\text { Qstb- } \\
\text { iau-27 }\end{array}$ & 1110173 & IP092034 & $6 \mathrm{~A}$ & 5125140 & 8.31 & 10.32 & TraesCS6A02G011000 & $\begin{array}{l}\text { F-box-like domain } \\
\text { superfamily }\end{array}$ \\
\hline $\begin{array}{l}\text { Qstb- } \\
\text { iau-28 }\end{array}$ & 1714673 & IP086013 & $6 \mathrm{~A}$ & 481341158 & 52.34 & 11.11 & & \\
\hline \multirow[t]{2}{*}{$\begin{array}{l}\text { Qstb- } \\
\text { iau-29 }\end{array}$} & 1009838 & IP002166 & $6 \mathrm{~B}$ & 129858768 & 25.34 & 9.98 & TraesCS6B02G133000 & $\begin{array}{l}\text { Leucine-rich repeat } \\
\text { domain superfamily }\end{array}$ \\
\hline & 5411274 & IP002166 & $6 B$ & 116289475 & 27.9 & 8.74 & & \\
\hline \multirow{4}{*}{$\begin{array}{l}\text { Qstb- } \\
\text { iau-30 }\end{array}$} & 2275399 & IP098022, RM6 & $6 B$ & 433578091 & 39.9 & 10.99 & & \\
\hline & 2347466 & IP098022 & $6 B$ & 655293076 & 40.9 & 9.93 & & \\
\hline & 4009529 & IP098022 & $6 B$ & 655131090 & 40.9 & 9.62 & & \\
\hline & 5577074 & IP098022 & $6 \mathrm{~B}$ & 655271759 & 41.2 & 10.68 & & \\
\hline $\begin{array}{l}\text { Qstb- } \\
\text { iau-31 }\end{array}$ & 3533124 & RM230 & $6 \mathrm{~B}$ & 694538538 & 67.59 & 13.32 & TraesCS6B02G425900 & $\begin{array}{l}\text { Protein kinase-like } \\
\text { domain superfamily }\end{array}$ \\
\hline \multirow{3}{*}{$\begin{array}{l}\text { Qstb- } \\
\text { iau-32 }\end{array}$} & 3534038 & RM22 & $6 \mathrm{D}$ & 457715429 & 93.5 & 7.86 & & \\
\hline & 1087865 & RM22 & $6 \mathrm{D}$ & 457764345 & 93.64 & 7.93 & TraesCS6D02G372800 & $\begin{array}{l}\text { P-loop containing } \\
\text { nucleoside } \\
\text { triphosphate } \\
\text { hydrolase }\end{array}$ \\
\hline & 3385440 & RM6 & $6 \mathrm{D}$ & 458145178 & 94.89 & 8.61 & & \\
\hline $\begin{array}{l}\text { Qstb- } \\
\text { iau-33 }\end{array}$ & 1110149 & IP099031 & $7 \mathrm{~A}$ & 4926154 & 8.1 & 7.76 & & \\
\hline \multirow{4}{*}{$\begin{array}{l}\text { Qstb- } \\
\text { iau-34 }\end{array}$} & 1252690 & IP086013 & 7B & 642235430 & 74.85 & 10.97 & & \\
\hline & 1219032 & IP086013 & $7 \mathrm{~B}$ & 641768856 & 75.01 & 10.98 & & \\
\hline & 1862701 & $\begin{array}{l}\text { IP086013, RM6, RM22, } \\
\text { RM183 }\end{array}$ & $7 B$ & 640866719 & 75.1 & 11.08 & TraesCS7B02G375500 & $\begin{array}{l}\text { SKP1/BTB/POZ } \\
\text { domain superfamily }\end{array}$ \\
\hline & 1082370 & RM183 & $7 B$ & 641707464 & 75.2 & 9.41 & & \\
\hline
\end{tabular}

Page 16/20 


\begin{tabular}{|llllllllll|} 
& 3953273 & IP086022 & 7B & 642461037 & 75.27 & 10.97 & TraesCS7B02G378100 & $\begin{array}{l}\text { Terpene synthase, N- } \\
\text { terminal domain } \\
\text { superfamily }\end{array}$ \\
\hline & 1093433 & $\begin{array}{l}\text { IP086013, RM6, RM22, } \\
\text { RM183 }\end{array}$ & 7B & 640867333 & 75.38 & 11.02 & TraesCS7B02G375500 & $\begin{array}{l}\text { SKP1/BTB/POZ } \\
\text { domain superfamily }\end{array}$ \\
\hline $\begin{array}{l}\text { Qstb- } \\
\text { iau-35 }\end{array}$ & 3020733 & RM22 & 7B & 642245907 & 75.95 & 10.97 & TraesCS7B02G377400 & $\begin{array}{l}\text { Aspartic peptidase } \\
\text { domain superfamily }\end{array}$ \\
\hline $\begin{array}{l}\text { Qstb- } \\
\text { iau-36 }\end{array}$ & 4989608 & RM183 & 7D & 15219082 & 11.07 & 8.84 & & Haem peroxidase \\
\hline $\begin{array}{l}\text { Qstb- } \\
\text { iau-37 }\end{array}$ & 2242097 & IP0323 & 7D & 5117520 & 11.5 & 7.76 & & \\
\hline
\end{tabular}

\section{Figures}
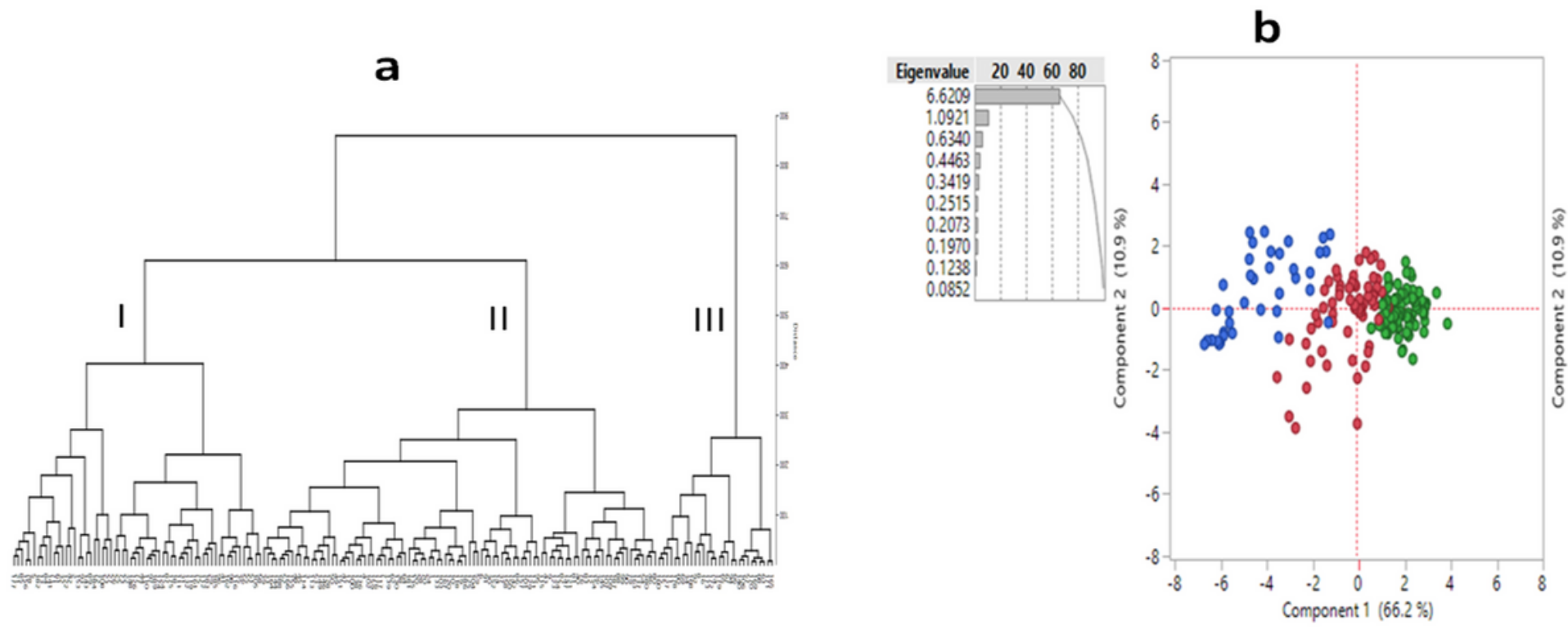

Figure 1

Cluster analysis (a) and principal component analysis (PCA) of 185 wheat genotypes based on mean disease severity data against ten Zymoseptoria tritici isolates.
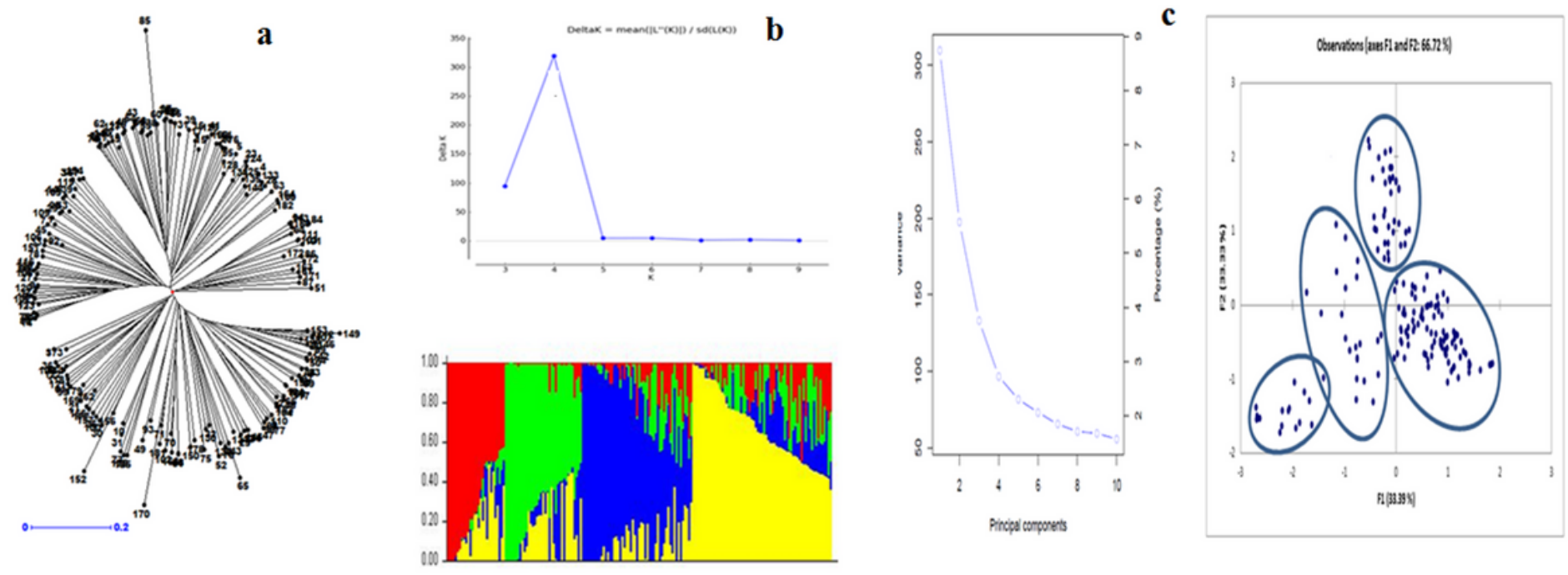


\section{Figure 2}

The neighbor-joining cluster analysis (a), determination of the optimal value of $\mathrm{K}$ and population structure analysis (b) and principal coordinate analysis (c) of 185 wheat genotypes based on DArTseq markers
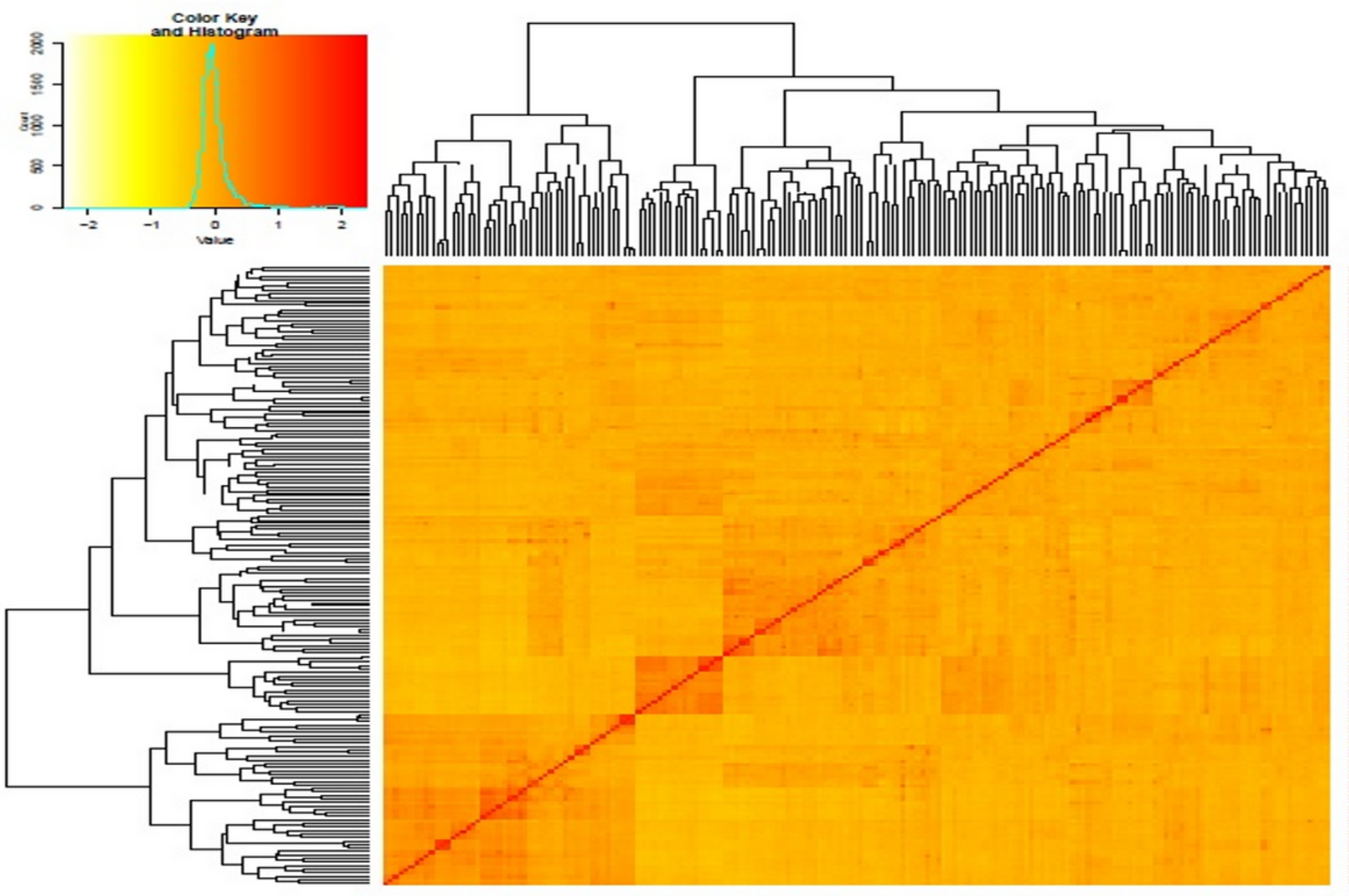

Figure 3

Heatmap plot of kinship matrix displaying relationships of 185 wheat genotypes based on DArTseq markers. 


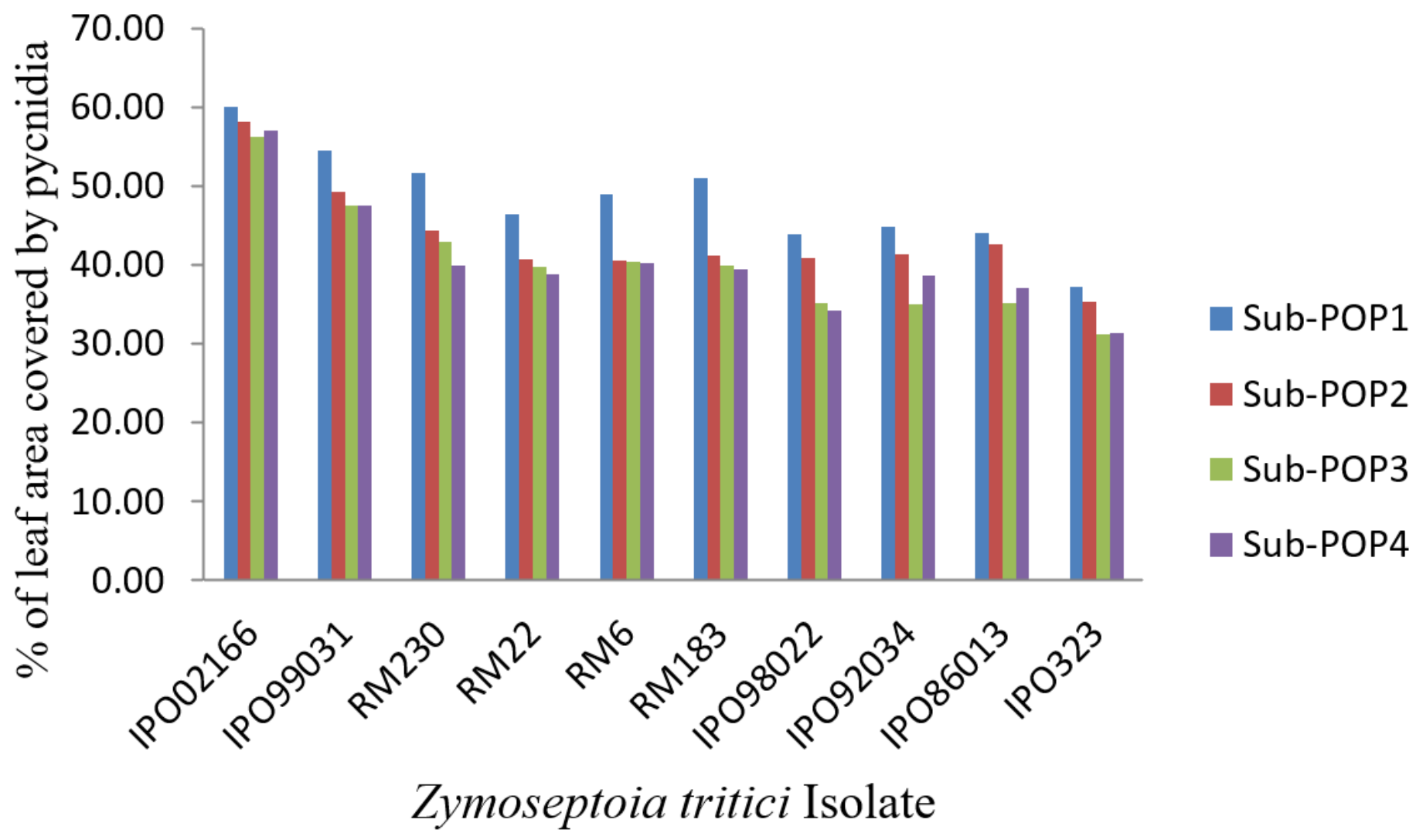

Figure 4

Different sub-population of 185 wheat genotypes panel that showed a different level of septoria tritici blotch disease severity (measured using the percentage of leaf area covered by pycnidia)

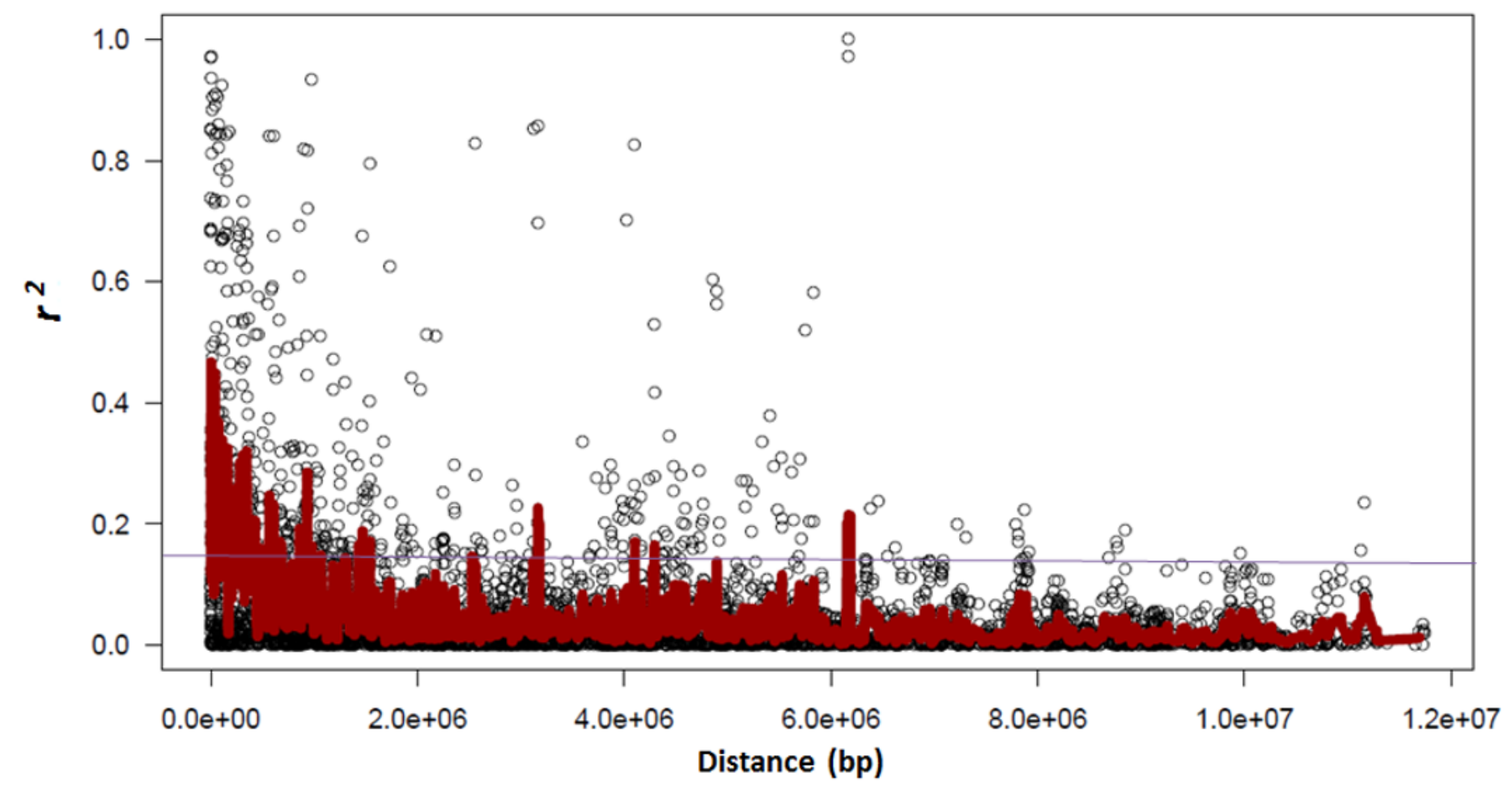


Figure 5

Linkage disequilibrium (LD) measured r2 plotted vs. the physical map (bp) between pairs of DArTseq markers in a panel of 185 wheat genotypes

\section{Supplementary Files}

This is a list of supplementary files associated with this preprint. Click to download.

- SupplementaryFigure1.tif

- SupplementaryFigure2.pdf

- SupplementaryTableS1.xIsx

- SupplementaryTableS2.xlsx 